\title{
THE HORMONAL CONTROL OF BODY SODIUM
}

\author{
J. D. H. SLATER, M.A., M.B., M.R.C.P. \\ First Assistant, The Medical Unit, Middlesex Hospital, W.1.
}

Our body cells are bathed in a fluid whose salt content resembles that of the primordial sea where we presumably had our origins several billion years ago. Since this sea probably contained about one-third as much salt as sea-water to-day (Strauss, 1957) its salt content approached that of our extracellular fluid. Among invertebrates there are wide variation in the osmotic concentration of body fluids, but the "milieu intérieur" of man and all classes of vertebrates is remarkably constant, both osmotically and volumetrically. Claude Bernard's (1878) oft-quoted idea that this stability was "la condition de la vie libre, indépendante" still appears axiomatic. When not associated with changes of the volume of body fluid compartments, quite large fluctuations of serum osmolarity are tolerable but when, as is more usual, changes in the volume of the body fluid compartments take place, then, the "freedom and independence of existence" is clearly curtailed.

Since salt balance can be preserved indefinitely on a diet as low in sodium as the dietician's ingenuity can fashion it, there must be potent renal mechanisms for the conservation of salt; without these mechanisms our aquatic ancestors presumably could never have migrated from salt to fresh water.

The volume of the extracellular fluid depends on its salt content since sodium, which is actively extruded from cells, largely determines its osmolarity. The total amount of sodium in the body is therefore very delicately controlled, and, allowing 3 to 4 days for equilibration, sodium output exactly equals sodium intake. In normal people extrarenal sodium losses are negligible if sweating is avoided, so that salt balance can only be achieved by variations of sodium output through the kidney. Looked at in another way, our very survival depends on the ability of the kidney to reabsorb the 173 litres of water and 24,000 milliequivalents of sodium filtered by the glomeruli each day. On an average salt intake about 99.5 per cent of the glomerular filtrate must be reabsorbed to maintain a steady state. Large changes of intake induce only very small changes in sodium reabsorption; a change of only 0.75 per cent in the amount of sodium reabsorbed will maintain a steady state despite doubling or halving an average salt intake. Therefore, the mechanism(s) by which the kidney is able to detect and respond to changes in salt intake must be very sensitive indeed.

\section{Mechanisms of Salt Excretion}

Much data is now available which strongly suggests that the volume of the extracellular fluid (ECF), or rather that portion of it which is physiologically effective, is one of the main factors which determines the rate of renal sodium excretion, at least in normal individuals (Epstein, 1956, Strauss, 1957, Smith, 1957). How is the kidney able to regulate it?

The kidney can only alter the rate of sodium excretion by two mechanisms-by changes in the rate of glomerular filtration (GFR) or by changes in the rate of tubular reabsorption. GFR is determined by hæmodynamic factors such as the renal blood flow and the relative resistance to flow offered by the afferent and efferent arterioles of the glomerular tuft and by the colloid osmotic pressure of the plasma proteins. The factors governing the rate of sodium reabsorption by the tubules will be tentatively assessed in this account because it is likely that hormonal, or at least humoral, factors are important.

For years there has been an earnest controversy concerning the relative importance of glomerular filtration and tubular reabsorption in mediating functional adjustments of sodium excretion. Wesson (1957) and O'Connor (1962) have been articulate protagonists of the idea that functional alterations of sodium excretion are largely determined hæmodynamically by indetectably small changes in filtration rate. If, but only if, we assume that the rate of tubular sodium reabsorption is constant and unrelated to the sodium load, then a 1 per cent change in GFR for a given plasma sodium concentration could halve or double the rate of sodium excretion. By present methods of estimation, such a small change of GFR lies within the limits of experimental error, so that the hypothesis becomes rather sterile because it cannot be tested experimentally. It is certainly true, however, that all the rapid changes in the rate of sodium excretion seen with manœuvres such as motionless standing, salt infusions and acute sequestration of blood or hæmorrhage are also associated with parallel changes of the rate of glomerular filtration. Qualitatively, even slight acute changes of GFR can lead to large changes of 
sodium excretion in the dog (Selkurt, 1951; Mueller, Surtshin, Rolf and White, 1951), but quantitatively the relationship between the two is quite unknown (Wesson, 1957). It cannot be assumed, as is often the case, that there is a sort of immutable, instantaneous "glomerulo-tubular balance" so that a fixed proportion of the filtered load is always reabsorbed. For example, there may well be a lag after an acute reduction of GFR before the rate of tubular reabsorption is also reduced. This, therefore, makes it impossible to decide from acute experiments whether a given fall of GFR, detectable or not, can account for an observed fall of the rate of sodium excretion. When, however, GFR and sodium excretion move in opposite directions or when there is a large and unequivocal change of GFR without a corresponding change of sodium excretion, then tubular reabsorption must be changing. This is well illustrated by the experiments of Black, Platt and Stanbury (1951). After some days of sodium deprivation in normal people, a rapid infusion of hypertonic saline increased GFR unequivocally, but the rate of urinary sodium excretion still remained low.

Many acute experiments concerning renal salt handling have been performed in the dog, which appears to use changes of GFR to regulate sodium excretion to a greater extent than humans (Chalmers, Lewis and Pawan, 1952). This should temper undue enthusiasm for extrapolation from dog to man. Finally, when trying to interpret relatively short-term experiments, we should realise that a permanent change of GFR does not appear to disrupt sodium homeostasis (Surtshin, Rolf and White, 1951). Therefore, tubular reabsorption must also change, although adjustments to altered sodium intake probably occur more slowly.

Increased tubular reabsorption of sodium is by now well-established in patients accumulating odema fluid. The GFR is clearly below normal in cardiac failure, (Merrill, 1946) even when due allowance is made for age (Wesson, 1957), but there is now a large body of data (Davis, 1960) which strongly suggests that the rate of tubular sodium reabsorption is increased. In the hypoproteinæmic states (the nephrotic syndrome and cirrhosis of the liver) the GFR is not significantly different from normal (Wesson, 1957) and there are numerous welldocumented accounts of supranormal rates, as might be anticipated when the colloid osmotic pressure of the plasma is reduced. Since the urine of these patients is often practically devoid of sodium, to conclude that increased tubular reabsorption of sodium is largely responsible for the œdema, becomes inescapable.

Once one accepts that the rate of tubular reabsorption of sodium is the major variable in the control of renal sodium output in man, then the problem becomes that of detecting the factors which determine it.

\section{The Role of the Adrenal Cortex in Mediating Changes of Sodium Excretion}

The adrenal glands are necessary to maintain life, an action parallel to the "mineralocorticoid" activity of the steroid hormones which promote the reabsorption of sodium and the secretion of potassium by the renal tubules. However, the adrenocortical hormones only increase the rate of tubular sodium reabsorp- tion by such a small increment that sodiurn deficiency in adrenocortical failure can b overcome by a modest increase of salt intak Nevertheless, without the mineralocorticoid action of steroid hormones, our capacity ta: curtail sodium losses in the face of a reduces intake is seriously impaired. Lipsett and Peak son (1958) showed that even when adrena: ectomised patients are maintained on relativel high quantities of cortisone $(50-75 \mathrm{mg}$. daily by the fifth day on a low salt diet (when normal person would have reached equilibrium the rate of urinary sodium excretion was still some three to four times more than the intakew Nevertheless, the rate of sodium excretion dies fall by about half, in association with a sharg reduction of GFR.

The adrenal cortex normally only secretes sufficient amounts of three known steriods (cortisol, aldosterone and corticosterone) which are important physiologically. Under norma conditions and in physiological quantities the probably exert their mineralocorticoid effects. mainly on the distal tubule (Vander, Malvin? Wilde, Lapides, Sullivan and McMurray, $195 \$$ where they promote sodium reabsorption, bot in association with chloride and, more character istically, by increasing the rate of exchangego sodium with potassium and hydrogen i Whether adrenocortical steroid hormones e्a influence sodium reabsorption by the proxima tubule is still unknown but, by implication ( $v$. infra), they appear to do so.

Of the steroids involved, it can be roughl calculated from the known potency ratios i animals (O'Connor, 1962) and the estimated rate of secretion from turnover studies after the injection of radioactive tracers in man, that about 70 per cent of the "mineralocorticoid" activity leaving the gland under normal condis tions is due to aldosterone, about 20 per cent to cortisol and about 10 per cent to corticost8 erone. Aldosterone is, then, the predominan mineralocorticoid despite the fact that the rate of cortisol secretion, which accounts for oves 90 per cent of the "glucocorticoid" activit leaving the adrenal, is 100 times greater gravimetrically. By "mineralocorticoid activity" is meant either the overall effect of prolonging the life of an adrenalectomised animal or the more specific effect of reducing the rate urinary sodium excretion. Actually, since cortisol (and its synthetic analogues) but now aldosterone or desoxycorticosterone increases the glomerular filtration rate in adrenalecto mised dogs (Garrod, Davies and Cahill, 1955 Slater, Mestitz, Walker and Nabarro, 196\$ 
some of the "mineralocorticoid" renal tubular effects of glucocorticoids are partially annulled. Thus adrenocortical steroid hormones, particularly aldosterone, do have biological attributes which could be evoked to explain many of the changes of the rate of sodium excretion which are seen physiologically and pathologically.

\section{Aldosterone and Sodium Homeostasis}

Aldosterone was first isolated in 1953 by Tait, Simpson and Grundy by a brilliant and painstaking combination of chemical analysis and biological assay for mineralocorticoid activity of the "amorphous" fraction of adrenal gland extracts. This fraction was known to be the most potent in maintaining life after adrenalectomy. Once discovered, aldosterone soon came to be regarded as a major factor in regulating renal sodium excretion via changes in the rate of tubular reabsorption, not only in odematous conditions, but also in physiological situations such as sodium depletion and repletion, the erect and supine posture, and hæmorrhage. Really good evidence regarding the role of aldosterone in these situations has been slow in coming despite many thousands of somewhat confusing publications. Evidence is needed that changes in the rate of sodium excretion are indeed associated with changes in the amount of biologically-effective aldosterone available to the renal tubular cells. The closest approach to this would be to measure the concentration of aldosterone in the circulating plasma and to assume that the ratio between free and protein-bound forms of the hormone found in the plasma also holds true at the cell surface. But aldosterone circulates in such minute quantities (of the order of tens of mille-micrograms or nanograms per $100 \mathrm{ml}$.) that a direct measurement of the plasma concentration is barely possible, even today. Another approach would be to try and obtain an index of the 24-hour average plasma level by measuring the rate of excretion of biologically active hormone in the urine. However, only a minute proportion of secreted aldosterone is excreted unchanged in the urine (about 0.2 per cent). Therefore, use has invariably been made of the fact that about 5 per cent of secreted aldosterone can be released from a conjugate by acid hydrolysis of the urine. This is now thought to be an 18-glucoronide (formerly Tait's 3-oxo-conjugate). The aldosterone so liberated can then be measured either biologically or, with greater precision, chemically. Quite apart from the inherent inaccuracies of measurement, the rate of excretion of acid-released aldosterone will only reflect the plasma level if (1) the renal clearance rate of the hormone is constant and (2) the proportion of the total secreted aldosterone metabolised along this particular metabolic pathway also remains constant. For example, a 5 per cent reduction of the 95 per cent of aldosterone present in the form of other metabolites could double the amount of aldosterone which can be released by acid hydrolysis.

The more recent application of radioisotopic procedures for the indirect measurement of the secretion rate of aldosterone (Laumas, Tait and Tait, 1961; Peterson 1959) has been a great stimulus, but to infer that a change of secretion rate implies a corresponding change of plasma level makes the assumption that the rate of metabolic disposal is constant. Actually, if the rates of both secretion and metabolic clearance are known, it is possible to arrive at an indirect measure of the plasma level of aldosterone.

With these remarks, it will be seen how the whole question of the relationship between the likely changes in plasma aldosterone concentration which could influence renal tubular activity, and the changes in sodium excretion, is bedevilled by almost insurmountable problems of measurement. It is, perhaps, all the more? surprising, that there is a considerable amount of good evidence which points to an inverse relationship between the rate of aldosterone excretion and the rate of sodium excretion both in œdematous states and in the physiological response of the kidney to changes of extracellular fluid volume (Leutscher and Johnson, 1954; Davis, Goodkind, Pechet and Bahu, 1956; Duncan, Liddle and Bartter, 1956). But even if the rate of excretion of the acidreleased metabolite does reflect the plasma level, to observe such a relationship does not necessarily imply that the one causes the other. Even though adrenalectomised patients, maintained on adequate steroid replacement therapy, cannot achieve sodium balance on a low sodium diet, this should not in any sense imply that the adrenal glands also mediate changes of sodium excretion under normal circumstances. It may mean only that some adrenocortical steroid activity is necessary, and that the changes of aldosterone level observed are not within the range of responsiveness of the renal tubules. Indeed, the idea that they are not so involved, but merely provide a sort of obligatory biochemical backcloth against which other factors actually mediate physiological 
changes has been espoused under the term the "permissive" action of the steroids (Ingle, 1952). It is certainly difficult to demonstrate renal tubular effects when aldosterone is given to normal dogs although it is easy to do so after adrenalectomy (Barger, Berlin and Tulenko, 1958).

One approach to the problem is to follow the relationship between the rate of renal sodium excretion and some index of the plasma level of aldosterone as a function of time during the course of the renal response to sodium deprivation. This was done by Crabbé, Ross and Thorn (1958) who measured the rate of urinary excretion of acid-released aldosterone. They were unable to obtain a significant relationship between the urinary sodium output and the urine output of this particular aldosterone metabolite. In view of the foregoing remarks this is not surprising, although they were able (Thorn, Ross, Crabbe and Van't Hoff, 1957) to show an inverse relationship between urine sodium excretion and acid-released aldosterone excretion in random urines collected from normal people.

Another, theoretically more profitable line is to observe the effects of an antagonist of aldosterone at the tubular level. One such, a 17-spirolactosteroid now marketed as spironolactone, was synthesised by Kagawa, Cella and Van Arman (1957) who were able to show in rats that the compound, whose chemical structure was designed to resemble that of aldosterone and so inhibit its action competitively, was biologically inert unless the adrenal glands were present. In dog and man the pharmacological properties of spironolactone in doses which are too low to have any physiological or toxic effect are, convincingly, only those of a mineralocorticoid antagonist at the renal tubular level (Liddle, 1958; Slater, 1960). Ross and Winternitz (1961) have shown that, in a single subject taking spironolactone, sodium deprivation modifies the renal response so that after five days on a rice diet containing only $3 \mathrm{mEq}$ of sodium, equilibration with intake had still not been reached; furthermore, the rate of fall of urinary sodium excretion (half-time 1.45 days) was significantly slower than the rate of fall observed in normal subjects (mean half-time 0.54 days SD 0.12 days). However, Mills (1963) in a similar experiment was unable to find evidence that the diurnal fluctuations of urine sodium output are even partly aldosterone-dependent.

The role of aldosterone in mediating changes of sodium excretion in short-term experiments is even more dubious. Quite apart from hæmodynamic factors, it is a puzzling anc challenging fact that there is a delay of $u$ to one hour before the renal tubular effects of injected steroid are apparent, even when the steroid is brought into intimate contact with the effector organ. This was clearly showr by Barger, Berlin and Tulenko (1957), and confirmed by Ganong and Mulrow (1958), who injected d-aldosterone directly into one renab artery; the characteristic effect on sodium and potassium excretion was seen simultaneously in both kidneys some 30-60 minutes later. This would appear to exclude aldosterone from $\vec{w}$ mediating at least the early changes of sodium excretion in such manœuvres as motionles standing, hæmorrhage and acute salt loading Furthermore, Addisonian or adrenalectomised patients maintained on an adequate ands constant amount of replacement steroid can manipulate their rate of sodium excretion in an apparently normal fashion, following botho quick changes of posture and sequestration of blood in the legs (Rosenbaum, Papper and Ashley, 1955; Epstein, 1956). We may reasono ably conclude, therefore, that hæmodynamien factors are dominant in experiments wherechanges of sodium excretion are seen withing minutes or possibly hours, but that there some evidence to suggest that alterations aldosterone levels are a major variable ins determining long-term adjustments to alteredo sodium intake. The evidence is incomplete indirect and hardly justifies any idea that aldosterone controls renal sodium excretion in $\overrightarrow{\overrightarrow{0}}$ the way that the antidiuretic hormone controls 3 urine flow.

\section{Aldosterone and Oedema Formation}

Whatever the final conclusion regarding the role of aldosterone in mediating changes of. salt excretion physiologically, a reasonable case can be made, with certain assumptions ( $v$. infra), for its being a major factor in the pro-o duction of odema, at least that of liver and renal disease. From a large literature, three. main pieces of evidence appear to predominate Davis, Howell and Southworth (1953) have shown that the excessive fluid retention which 0 can be induced in dogs by constricting the thoracic inferior vena cava-an excellento stimulus to aldosterone production-could onlyo be mimicked after adrenalectomy if desoxy corticosterone acetate (DOCA) was given in ${ }^{\circ}$ 20 to 50 times the amount needed for full replacement in otherwise untouched adrena응 lectomised dogs. 
Similarly, Giroud and his colleagues (1961) have demonstrated that aminonucleoside nephrosis in rats is adrenal-dependent. To reproduce the fluid retention seen in animals with intact adrenal glands, ten times the amount of aldosterone necessary for replacement in normal animals was required.

Finally, in man, the effect of the 17-spironolactosteroids when given to patients with cirrhosis of the liver or the nephrotic syndrome can be so dramatic that all the visible odemafluid disappears. Usually, however, the effect is relatively small. Since, from the doses used, competition with aldosterone for receptor sites on the renal tubule is far from being on a molecule-for-molecule basis, the fact that spironolactone is usually a weak diurectic may only mean that the effect of aldosterone on the renal tubule is only partially inhibited in the quantities used. It is, perhaps, considerably more significant that an odematous patient can be rendered "dry" by spironolactone alone. In cardiac failure the effect of aldosterone antagonism is small (Bartter, Gann and Thomas, 1960) unless cardiac cirrhosis of the liver has supervened (Slater, 1960) but then, hæmodynamic factors predominating, hyperaldosteronism is usually not a conspicuous feature of cardiac failure in contrast to the intense hypersecretion of aldosterone in patients with the nephrotic syndrome or cirrhosis of the liver.

But, if inappropriate overproduction of aldosterone is really important in odema formation, prolonged administration of aldosterone or other mineralocorticoid steroid hormones such as desoxycorticosterone might be expected to lead to sodium retention and ultimately the appearance of cdema. This does not happen (August, Nelson and Thorn, 1958). By some mechanism which may be hæmodynamic or may involve a process of tubular antagonism, an "escape" from the effect of mineralocorticoids on ion transport occurs. The timing of this "escape" will vary with the salt intake and the dose of steroid used, but in normal people and in animals it always occurs. It may have its pathological counterpart in the syndrome of primary aldosteronism when œdema is strikingly absent and hypokalæmia prominent. This contrasts with the fluid retention and normal serum potassium levels seen in the secondary hyperaldosteronism of cirrhosis and nephrosis.

It is therefore clear that, for fluid retention to take place, there must be some other important factor operating apart from an increased circulating level of aldosterone. Whatever its nature, whether humoral or circulatory, it would appear likely that its main effect is to increase the rate of proximal tubular sodium reabsorption. If this is greatly enhanced it can be reasonably argued that insufficient sodium is delivered either to the site of freewater formation or to the site of exchange between potassium and sodium further down the nephron. Impaired free-water excretion is a characteristic feature of odematous states (Ralli, Leslie, Stueck and Laken, 1951) and sodium depletion (McCance and Widdowson, 1937). It is unlikely to be due to excess antidiuretic hormone (Lamdin, Kleeman, Rubini and Epstein, 1956; Schedl and Bartter, 1960). In contrast to normal people, the infusion of mannitol into patients with cirrhosis of the liver or cardiac failure increases the free-water clearance (Bell, Schedl and Bartter, 1964; Schedl and Bartter, 1960). Similarly, potassium depletion is conspicuous by its absence in the secondary hyperraldosteronism of untreated patients with cirrhosis and nephrosis. Since tubular potassium secretion largely occurs in exchange for sodium (Berliner, Kennedy and Hilton, 1950), a reduced delivery of sodium to the distal tubule will reduce the urinary loss of potassium that would presumably otherwise occur in response to high levels of circulating aldosterone.

From the fact that 85 per cent of filtered sodium is reabsorbed proximally, it is clear that an influence which even slightly changed the rate of this erstwhile "obligatory" sodium reabsorption would have a profound influence on the rate of renal sodium excretion. Since the fluid retention of cirrhosis of the liver appears to be largely aldosterone-dependent, and since proximal tubular sodium reabsorption is enhanced in this condition, it can be argued that aldosterone must be acting on the proximal tubule.

\section{Non-Adrenal Factors Influencing Tubular Sodium Reabsorption}

Others have sought to discover evidence for non-adrenal factors affecting tubular reabsorption. The posture and thigh-cuffing experiments of Rosenbaum, Papper, and Ashley (1955) in adrenalectomised patients were continued for several hours; the rate of urine sodium excretion remained low despite a clearly rising rate of glomerular filtration. Since the quantity of steroid replacement was constant, the authors felt compelled to postulate the existence of some other non-adrenal factor which promotes 
tubular sodium reabsorption. But this interpretation cannot be accepted until we know whether the circulatory level of biologicallyactive steroid was, in fact, constant. Changes of posture are known to change the rate of liver blood flow which may well be a critical factor in determining the steroid plasma level.

Ingenious cross-circulation experiments with correction for fluid displacements have been performed by de Wardener, Mills, Clapham and Hayter (1961) in an attempt to avoid the vexed question of whether saline infusions increase renal sodium excretion hæmodynamically or by changes of tubular reabsorption. In 3 experiments, when supramaximal quantities of anti-diuretic hormone (with a mineralocorticoid to suppress aldosterone production) were given to both dogs, the saline-infused animal nevertheless excreted much more sodium than the other despite apparently equivalent changes of filtered sodium load. It was therefore concluded that changes in the concentration of an ephemeral hormone, other than aldosterone, was responsible.

\section{The Control of Aldosterone Secretion}

Whatever the final conclusion about the precise rôle of aldosterone in the preservation of salt balance, its import cannot be denied, particularly in œdema formation. We have seen how renal sodium excretion appears to be largely a function of the extracellular fluid volume and that under most circumstances the rate of renal sodium excretion varies inversely with the rate of excretion of the acidreleased urinary conjugate of aldosterone. Assuming this reflects the plasma level and assuming that the plasma level is largely a function of the rate of secretion, it would appear reasonable to predict that changes of extracellular fluid volume would be a major factor influencing the rate of aldosterone secretion.

\section{Changes of extracellular fluid volume}

The excellent series of experiments by Bartter and his colleagues in man (Bartter, Mills, Biglieri and Delea, 1959) clearly showed that an expansion of the extracellular fluid (ECF), whether associated with an increase, no change, or a decrease in the volume of intracellular fluid, reduced the rate of urinary excretion of the acid-released aldosterone metabolite and increased renal sodium excretion. Conversely a contraction of ECF volume, whether associated with a decrease or an increase in the volume of the intracellular fluid, increased the rate of aldosterone excre- tion and reduced renal sodium excretiona Finally, it was shown, by infusing salt-poo albumin, that expansion of the intravasculao fluid alone would still produce a fall in therate of aldosterone excretion. Since there was $\overrightarrow{\text { क }}$ net decrease in the total ECF volume, this is most convincing demonstration that it is intra vascular and not interstitial cell volume that matters. If we assume that the excretion of aldosterone, as the acid-released conjugate mirrors its secretion, then changes of blood volume are at least one factor likely to have a profound influence on the latter. But how is the adrenal able to sense these changes?

Changes of electrolyte composition of the extracellular fluid

Concomitant alterations of the plasma cons centration of sodium or potassium were explored particularly by the Australian workers (Blair-West, Coghlan, Denton, Goding, Munro: Peterson and Wintour, 1963; Coghlan, Dentono Goding and Wright, 1960). They transplan? the one remaining adrenal gland of a sheep into its neck so that local changes in composition of the blood supplying the glan $\overline{\$}$ can be made without disturbing the rest of the animal. The rate of steroid secretion cano then be measured directly, and in selectes animals the transplant retains apparen normal responsiveness for years; it may ever grow medullary tissue. Local infusions of glucose to lower the plasma sodium concentra tion by clinically large amounts are associate with only a small increase in the rate of aldosterone secretion. A relatively large in crease in the potassium concentration, however is a sharp stimulus to the secretion of aldo sterone, especially when accompanied by decrease of sodium concentration.

It is now clear that local changes of plasmá⿱ potassium concentration can also be an. important stimulus to aldosterone secretion ins the dog (Urquhart, Davis and Higgins, 1962) but, in man, very large changes of potassiun? balance only change the rate of aldosterones excretion to a relatively small extent wher appropriate compensation is made for the fact that potassium loss causes sodium retention and vice versa. Profound hyponatræmia follow: ing water loading in man is associated with ow low rate of aldosterone excretion, even where sufficient potassium is given to reduce sharplyo the plasma sodium-to-potassium ratio (Bartter Liddle, Duncan, Barber and Delea, 1956) $\rightarrow$ which again emphasises the physiologicalo insignificance of changes of plasma sodiun? and potassium concentration in man. 
If, then, it is the volume of the blood rather than its composition which is the major variable in regulating aldosterone secretion, what function of it provides the afferent stimulus? Under- or over-filling of the venous side is probably not important because a reduced amount of blood in the central veins (as in constriction of the thoracic inferior vena cava) and also distension of the central veins (as in cardiac failure) are both associated with hyperaldosteronism. With each, however, there is a tendency for inadequate filling of the systemic arterial tree which, it has been suggested, is a major influence on the rate of renal sodium excretion (Epstein, Post and McDowell, 1953). Therefore, localised receptor areas have been looked for in the arterial system. Already it appears that constriction of at least two major arteries, the carotid and the renal ( $v$. infra), will stimulate aldosterone production. Constriction of the carotid arteries was discovered by Bartter, Mills and Gann (1960) to be a strong stimulus to the secretion of aldosterone in normal dogs stressed by surgery. This was confirmed by Carpenter, Davis and Ayers (1961 $a$ and $b$ ) but, in their hands, the stimulus was a very weak one. Both this effect and the intense aldosterone-stimulating effect of acute constriction of the inferior vena cava in normal dogs stressed by surgery was found by Bartter and his colleagues to be prevented by prior removal of all visible nerves from the thyrocarotid arterial junction, but not by denervation of the carotid sinus. The significance of these exciting results was questioned when Carpenter and his colleagues showed that hyperaldosteronism persisted in dogs with chronic constriction of the thoracic inferior vena cava despite extensive stripping of all visible nervous tissue from the central arterial tree. Moreover, hypophysectomy greatly weakens the aldosterone-stimulating effect of acute, but not chronic, constriction of the inferior vena cava, and Biglieri and Ganong (1961) showed that after hypophysectomy, carotid artery compression failed to increase aldosterone secretion, although it would do so in normal animals. It could be argued that some ACTH is necessary "synergistically" and it certainly seems unlikely that all the acute effects described by Bartter, Mills and Gann (1960) can be explained on the basis of changes of ACTH production, but since these are extremely difficult experiments with a high biological and chemical variability, adequate interpretation must await further data. Certainly the more recent discovery that
ADRENAL EFFECTS OF

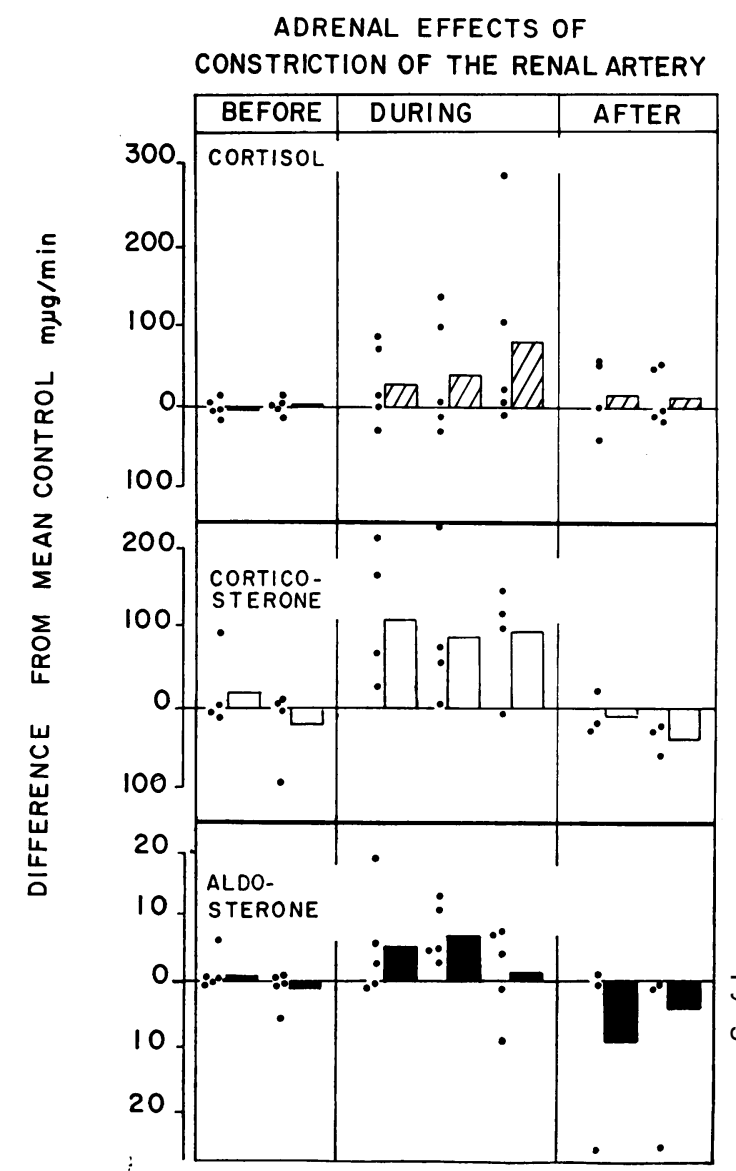

Fig. 1.-The effect of constriction of both renal arteries on the production of aldosterone, corticosterone and cortisol in 5 dogs hypophysectomised 6 to 14 days previously, plotted as a difference from the mean of the control data (Slater, Barbour, Henderson, Casper and Bartter, 1964). Each point is the secretion rate over a 20 to 30 minute period. Blood collections were started 35,70 and 95 minutes after constriction was applied. The constriction was then released and 2 final samples collected 60 to 75 minutes later. (By permission of SURGERY, GYNECOLOGY \& OBSTETRICS).

constriction of the renal arteries (Fig. 1) and hence the renin-angiotensin system ( $v$. infra) will stimulate the adrenal cortex in hypophysectomised dogs has temporarily eclipsed further work on other areas of the arterial tree.

On the efferent side, the regulation of aldosterone secretion has been shown to be hormonally, or at least humorally, mediated both in the sheep (Denton, Goding and Wright, 1959) and dog (Yankopoulos, Davis, Kliman and Peterson, 1959). This situation is also com- 
CORTISOL

Normal Hypox

CORTICOSTERONE

Normal Hypox

ALDOSTERONE

Hormal Hypox
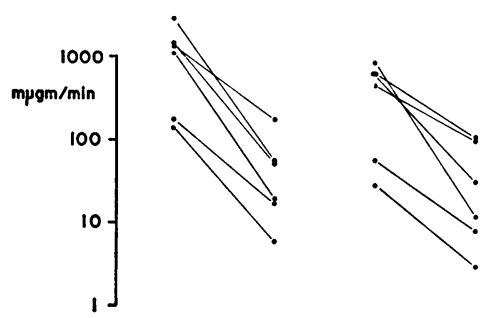

Fig. 2.-The rate of adrenocorticosteroid production before and 18 hours after hypophysectomy in 6 conscious dogs deprived of dietary sodium. Secretion rates have been calculated with allowance for the uptake of aldosterone by erythrocytes (Slater and others, 1964). Data plotted on a log-scale to emphasise proportional changes.

(By permission of THE JOURNAL OF CLINICAL INVESTIGATION).

plex but has been partially clarified by the recent discovery of the direct steroid-stimulating effects of angiotensin. Before considering this, two other potentially relevant hormonal mechanisms should be mentioned.

\section{The role of the pituitary}

By analogy with the ACTH-cortisol system the role of the pituitary gland has been extensively studied. Large doses of ACTH will certainly increase aldosterone excretion but the effect is short-lived in man even when sodium retention is prevented. Furthermore, suppression of the pituitary with cortisone does not reduce the rate of aldosterone excretion (Liddle, Duncan and Bartter, 1956). The pattern of adrenocortical stimulation with decreasing doses of ACTH in dogs shows quite clearly there is no dose of ACTH which stimulates aldosterone production without also stimulating the production of cortisol (Slater, Barbour. Henderson and Casper, 1963). A patient without his adrenal glands dies of sodium deficiency if deprived of salt, whereas a patient without his pituitary gland conserves salt normally (MacLean, Lipsett, Li, West and Pearson, 1957) and dies eventually of cortisol deficiency without gross electrolyte imbalance. After hypophysectomy the zona glomerulosa of the adrenal gland, where aldosterone is produced, does not atrophy, whereas the zona fasciculata, where cortisol is produced, does. Even from the evidence available in 1940, Swann was able to postulate the existence of a separate nonpituitary mechanism for the control of mineralocorticoid activity of the adrenal glands. Nevertheless, more recent work concerning the acute effects of hypophysectom in dogs appeared to implicate the pituitary (Davis, Bahn, Yankopoulos, Kliman an\& Peterson, 1959; Slater, 1963). Most of this wor was done in heavily anæsthetised dogs acutely stressed by surgery. To avoid this the effect of hypophysectomy by estimating the adrenocorti costeroid secretion rates has been assesse. before and some 18 hours after surgery, when the animal was calm and conscious (Fig. 2). A\$ was expected, aldosterone secretion does no $\overline{5}$ change despite sharp falls in the rate of cortisot and corticosterone secretion.

\section{Role of the pineal}

Since, therefore, the pituitary can be exclude as a major factor, Farrel produced thê phylogenetically fascinating idea that the funcof tion of the pineal gland was concerned with the control of aldosterone secretion (Farrelfs, 1958). He found that extracts of beef dience phalon stimulated the secretion of aldosterone in decerebrate dogs and that a large part of this activity could be accounted for by that present in the pineal gland (Farrell, 1959). But pinealectomy does not reduce aldosterone. secretion and the usual increase in aldosteren secretion following salt-deprivation is seen in pinealectomised dogs (Farrell, 1960). Unfortumo ately, experimental confirmation of the adreno glomerulotrophic effects of pineal extracts antक compounds therefrom is still awaited so thap at the present time it is virtually impossible to assess the importance of the pineal-hypothal $\overrightarrow{0}$ amic system. Nevertheless, it seems highly likely that the central nervous system is somehow involved, possibly in mediating fine adjustments? of aldosterone production, but it is clear from the work of Davis and his colleagues that. hyperaldosteronism in dogs can persist and be produced despite chronic extensive hypo thalamic lesions or even decapitation.

\section{The role of the kidneys}

The finding of Deane and Masson (1957) that, in the rat, renal extracts produce adrena?. hyperplasia, the discovery by Biron, Kiown Nowacynski, Brouillet and Genest (1961) that the adrenal glands are stimulated by angiotensino II in man and Bartter's description of hyper $-\mathrm{J}$ plasia of the juxtaglomerular complex in aO patient with hyper-aldosteronism due to bilaterab adrenal hyperplasia (1962), all suggested thato the kidneys may be important in the control of aldosterone via the renin-angiotensin system. Three separate groups in the United States? studied this simultaneously and independently 


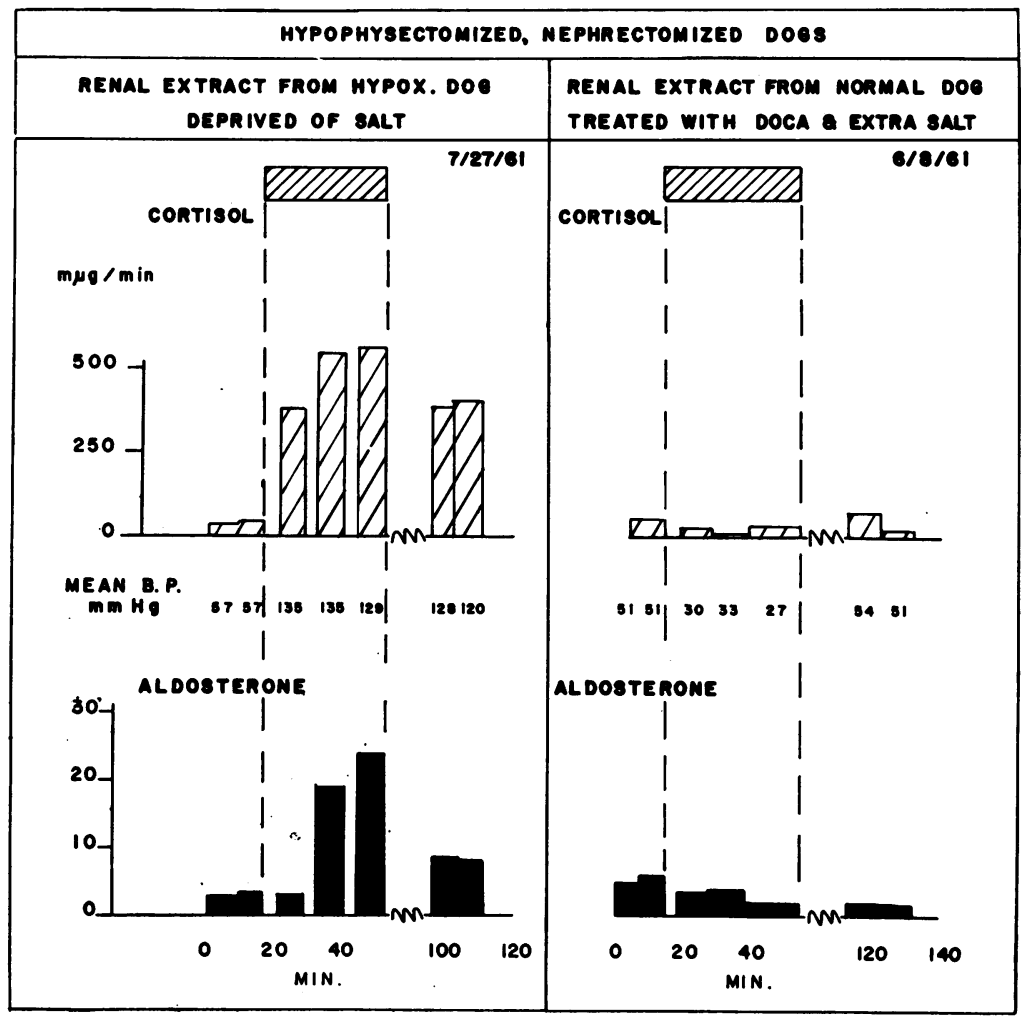

FIG. 3.-Adrenocortical response in dogs without pituitary or kidneys, to saline extracts of kidneys from (a) a hypophysectomised dog deprived of salt and (b) a normal dog loaded with salt.

in recently hypophysectomised dogs (Davis, Carpenter, Ayers, Holman and Bahn 1961; Ganong and Mulrow, 1962; Slater, Barbour, Henderson, Casper and Bartter, 1963, 1964). Each group found that nephrectomy uniformly reduced, if it did not abolish, the adrenocortical response to acute hæmorrhage, although the gland was still easily stimulated by ACTH. They each also showed that saline extracts of the kidney would stimulate the adrenal cortex. That this effect is not due to renal sequestration of ACTH but, rather, is related to the salt balance of the animal whose kidney is used, is indicated in Fig. 3. The effect of nephrectomy is, however, not so clear-cut. Performed as an acute experiment in recently traumatised, sodium-depleted, and hypophysectomised animals under heavy anæsthesia, nephrectomy sharply reduced the rate of aldosterone secretion to basal levels. There was, however, a relatively slight fall in aldosterone secretion seen in conscious or lightly anæsthetised hypophysectomised animals where one remaining kidney was removed with minimal trauma some 18 hours after major surgery (Slater, 1963). Similarly, Blair-West and his colleagues (1963) found that the rate of aldosterone secretion often remained well above basal in sodium-depleted sheep despite hypophysectomy and bilateral nephrectomy. More data on this important question is needed, but it is already clear that the kidneys do not produce a trophic substance affecting aldosterone secretion similar in importance, for example, to ACTH in the control of cortisol secretion. Nevertheless, the recent finding of extractable renin in the blood vessels (Gould, Skeggs and Kahn, 1964) may, if the amounts are sufficient, prove to be the explanation.

\section{The Renin-Angiotensin System}

As long ago as 1898 Tigerstedt and Bergman discovered that extracts of the kidney would raise the blood pressure. Following Goldblatt's demonstration in 1934 (Goldblatt, Lynch, Hanzal, and Summerville) that renal ischæmia produces hypertension, interest in the mechanism of this hypertensive effect of renal 


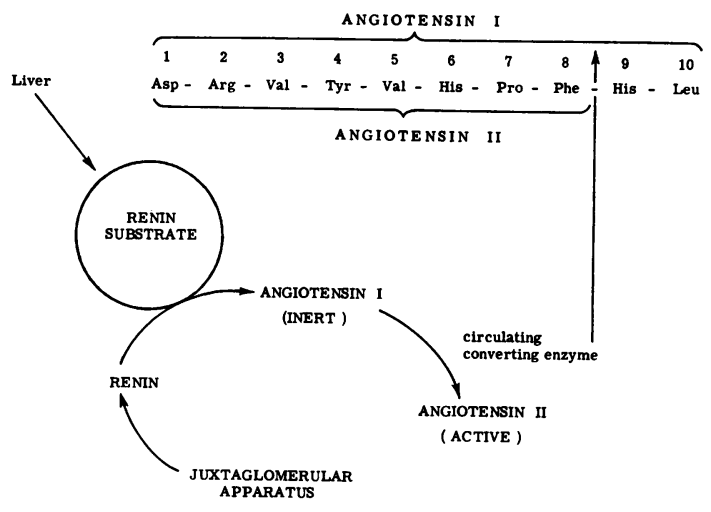

FIG. 4.-The renin-angiotensin system.

extracts was stimulated, chiefly with regard to the cause of hypertension. From the pioneer work of Page, Pickering, Braun-Menéndez and their collaborators (Page and Bumpus, 1961), it has now become clear that renal tissue contains a proteolytic enzyme, renin, which splits specifically a leucyl-leucine bond in a circulating $\alpha$-globulin of hepatic origin (renin substrate or angiotensinogen) to produce a largely inert decapeptide, angiotensin $I$. A circulating enzyme then splits off two aminoacids to produce angiotensin II, an octapeptide which is the most potent pressor substance known. Angiotensin is destroyed in a short time by potent enzymic systems, collectively known as "angiotensinase", which are present in all tissues and circulating blood. It is now almost certain that the renin liberated from the kidney originates in the granular cells of the juxtaglomerular apparatus (Cook and Pickering, 1958; Bing and Kazimierczak, 1962; Hartroft, Sutherland and Hartroft, 1964) and possibly even in the granules themselves (Skelton, Chandra and Bernardis, 1964). First described by Ruyter (1925), these cells were studied by Goormaghtigh (1945) as an example of the endocrine function of the renal arterioles. The granular or afibrillar cells are found in the media of the afferent arteriole, near the glomerular tuft. They always lie in contact with a group of specialised cells, the macula densa, in the

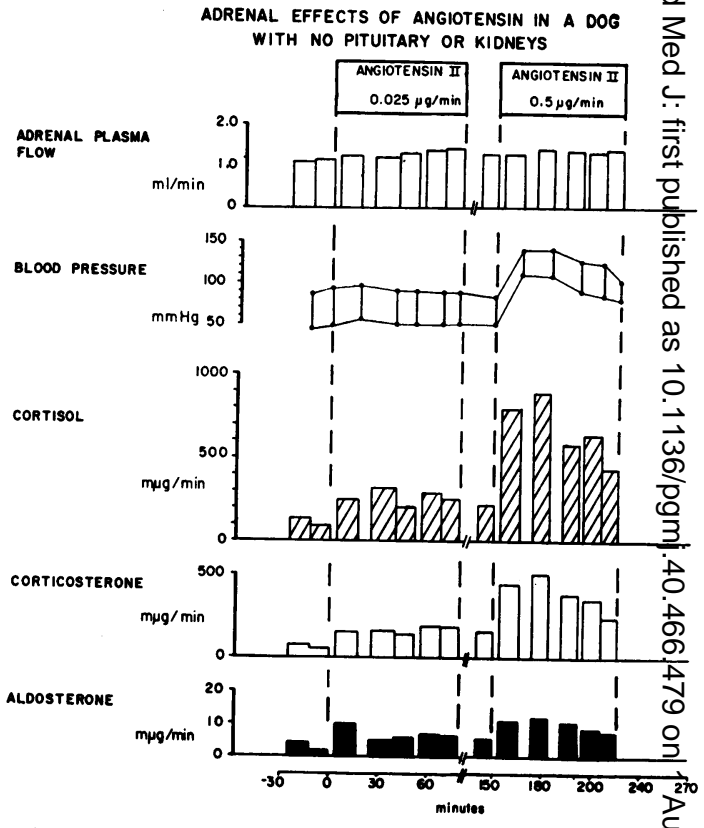

FIG. 5.-Pattern of adrenocortical response to angiotensin II in a hypophysectomised, nephrectomised

(By permission of THE JOURNAL OF CLIN INVESTIGATION).

distal convoluted tubule of the same nephir Teleologically this arrangement is dangerousy seductive-what better anatomical basis sensing the filling of the arterial tree? Fig. 4 shows the overall picture of the system today though, if this is anything like the broady analagous kinin-forming system, it will ső̋n require considerable modification.

The importance of angiotensin in the control of sodium metabolism has become evident $\overline{\text { In }}$ the past few years. Indeed, it appears possibie

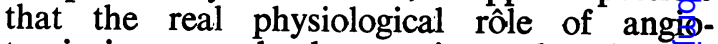
tensin is on renal salt excretion rather than on the control of blood pressure.

Angiotensin (or rather the synthetic aspartic $\beta$-amide) is a confusingly versatile molecue. Apart from being a senior member of the growing band of polypeptides which affectit smooth muscle (so that it may influence sodium excretion hæmodynamically) it stimulates the production of adrenocortical steroids, liberates catecholamines from the adrenal medutta (Feldberg and Lewis, 1963) and inhibits disfral tubular reabsorption of sodium (Vander, 196\%). To make the all-important separation of phatmacological from likely physiological effects is extremely difficult since we know so little aboḡt the circulating concentration of angiotensin. any case, the local concentration at the site of 
renin liberation in the juxtaglomerular complex may be quite different, and yet it is just here that angiotensin is in a strong position to influence the rate of both glomerular filtration and distal tubular sodium reabsorption. There are at least two obvious ways already known by which the renin-angiotensin system can influence renal sodium excretion. It can operate directly on the kidney or indirectly via the stimulation of production of aldosterone. The real question is whether angiotensin does, in, fact, and if so, under what circumstances.

\section{The role of the renin-angiotensin system in the} control of aldosterone secretion

The first problem concerns the dose-response relationship between angiotensin action and adrenocortical response. The critical criterion for the designation of angiotensin, or any other potential candidate, as an aldosteronestimulating hormone, is that it should affect the secretion of aldosterone almost exclusively. However, in the hypophysectomised, nephrectomised dog (Carpenter, Davis and Ayers, 1961; Mulrow, Ganong, Cera and Kuljian, 1962; Slater, Barbour, Henderson, Casper and Bartter, 1963) corticosterone secretion is stimulated to a comparable degree whatever the dose of angiotensin given, whereas Davis finds that constriction of the inferior vena cava barely alters corticosterone secretion in the conscious, minimally stressed dog (Davis, Carpenter, Ayers and Bahn, 1960). Slater and colleagues (1963) found, in addition, that whenever aldosterone secretion is clearly stimulated, so also is that of cortisol (illustrated in Fig. 4). But the rate of corticosterone and cortisol secretion reached is relatively modest compared with the effect of ACTH, which has quite a different pattern of adrenocortical stimulation (Slater and others, 1963; Mulrow and others, 1962). In the intact dog, the rate of equilibration of the ACTH-cortisol (and corticosterone) feed-back system may be sufficiently rapid to obscure changes of cortisol and corticosterone secretion in response to angiotensin. However, small amounts of angiotension II infused locally into the transplanted adrenal gland in the neck of a sheep, (BlairWest and others, 1962) usually do not increase the secretion of cortisol or corticosterone. Therefore, providing the responsiveness of these adrenal transplants can be validated, either there is a species difference or intravenous angiotensin injections promote cortisol secretion indirectly. With man, hypertensive quantities of angiotensin II do stimulate the urinary excretion of cortisol metabolites but this appears trivial compared with the considerable increase of excretion of aldosterone metabolites (Biron and others, 1961). In smaller, nonhypertensive, quantities an exclusive increase of aldosterone excretion, as the acid-released metabolite, is seen despite suppression of ACTH production with dexamethasone (Fig. 6). It is therefore possible that the pattern of adrenocortical response to angiotensin is compatible with that caused by salt-deprivation and other stimuli, though intense hyperaldosteronism is seen in many odematous patients without any apparent change of the rate of cortisol secretion, which implies the existence of some other variable. This may be the pattern of responsiveness of the adrenal zona glomerulosa. The Melbourne group have shown that in the saltdepleted sheep small doses of ACTH given locally stimulate the secretion of much more aldosterone in relation to cortisol than in the salt-repleted sheep (Blair-West, Coghlan, Denton, Goding, Wintour and Wright, 1963).

There is now little doubt that in secondary hyperaldosteronism, whether experimental or clinical, there is a considerable elevation of circulating renin-like activity (Brown and others, 1964; Fasciolo and others, 1964; Davis, Higgins, and Urquhart, 1964) which is often beyond the possible range of the likely error of the method. It has been known for some time that the amount of renin which can be extracted from rat kidneys (Gross and Lichtlen, 1958) is both reduced by salt-loading and mineralocorticoid administration and increased by salt deprivation or adrenalectomy. The granularity of the juxtaglomerular cells (Pitcock, Hartroft and Newmark, 1959; Tobian, 1960) varies similarly. If the renin-store diminshes as the rate of renin discharge diminshes (a somewhat surprising feature which, on indirect evidence, nevertheless appears to be true), then it implies that the rate of renin discharge varies inversely with the volume of the extracellular fluid and hence directly with the rate of aldosterone secretion.

It is still uncertain whether the circulating renin concentration rather than the concentration of renin substrate is the rate-limiting factor for the production of angiotensin physiologically, but, in dogs, sodium depletion, which Brown and his colleagues find increases the circulating renin concentration, does appear to elevate circulating angiotensin levels (Bartter, 1963; Scornik and Paladini, 1964). It must be said, however, that the whole question of the accurate and reliable assay of 
ANGIOTENSIN INFUSION IN HEALTHY PEOPLE

$0.25 \mu \mathrm{gm}$. per minute

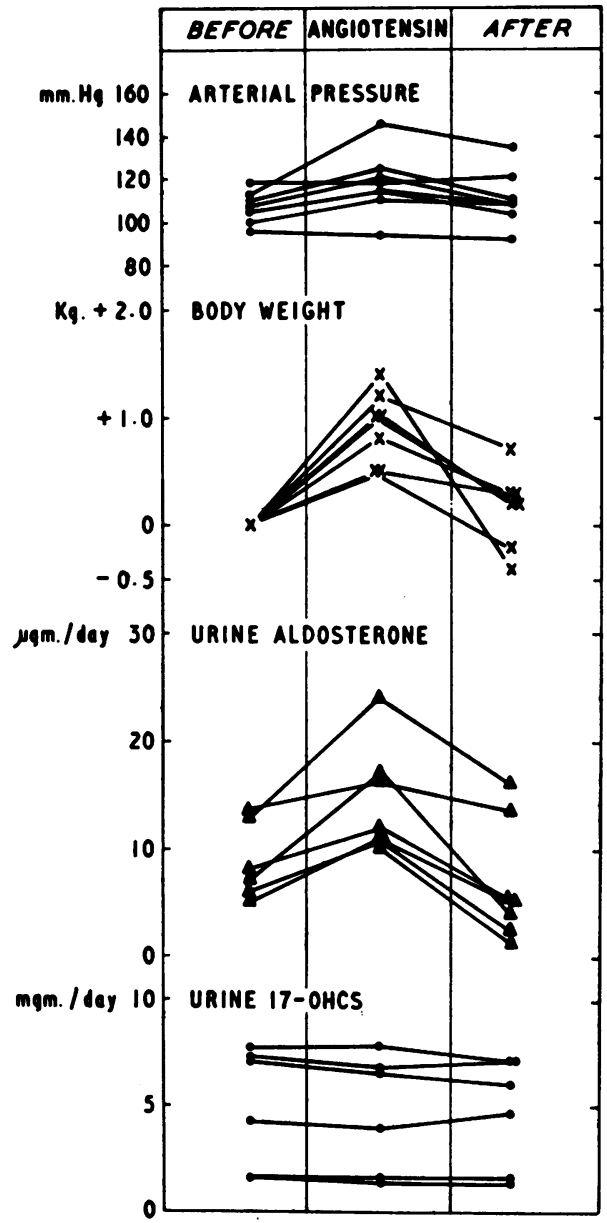

1962

Fig. 6.-Adrenal and metabolic effects of a 58-hour infusion of small amounts of angiotensin II in 7 healthy people, 2 of which (the lower 2 points under "urine 17-OHCS") were given dexamethasone.

renin and angiotensin in biological fluids on an analytical rather than preparative scale, is still overshadowed by methodological difficulties, although Boucher, Veyrat, le Chamlain and Genest (1964) have considerably simplified a very difficult method. That we are still on the threshold of our understanding of the role of the renin-angiotensin system in the control of aldosterone secretion is suggested by some recent findings. Van Brunt, Biglieri and Ganong (1964) find in renin-immunised dogs that the rate of aldosterone secretion is normal and that it increases with salt-depriva-

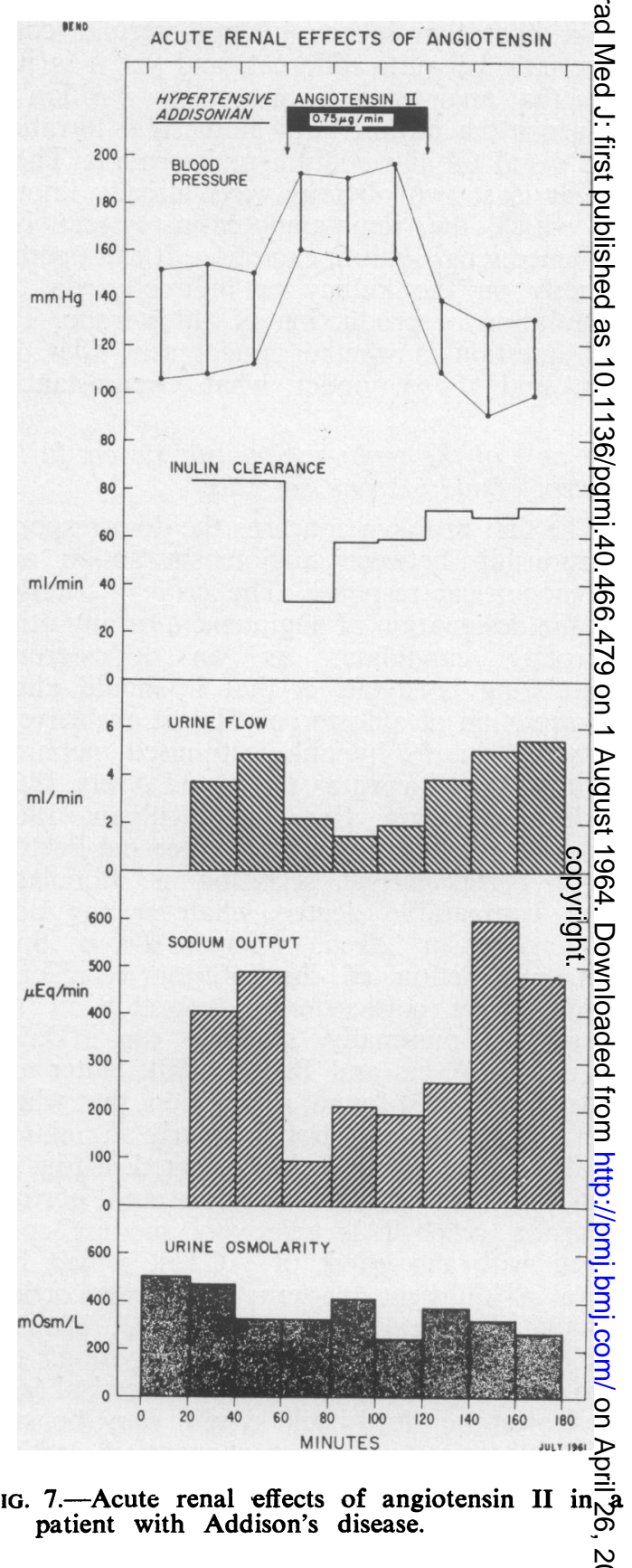

tion although the animals are unresponsive the pressor action of injected renin. This mEy only mean that there is still enough circulating angiotensin to mediate changes of aldosterone secretion, but it also may imply that other mechanisms for aldosterone control are dompnant in the normal, conscious dog. Anoth apparently incompatible finding is that of 
ADDISON'S DISEASE

B

E $37.5 \mathrm{mgm} . / \mathrm{day}$
ANGIOTENSIN

$\mu \mathrm{gm} . /$ minute $\left.\begin{array}{c}1.0 \\ 0.5 \\ 0\end{array}\right]$

$$
+1.0
$$

BODY WEIGHT $\triangle \mathrm{Kg}$

0
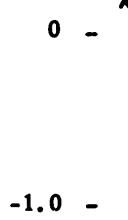

200

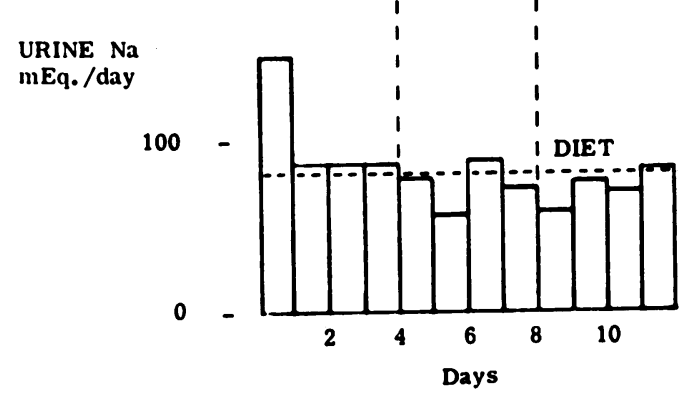

METABOLIC EFFECTS OF ANGIOTENSIN
5 HEALTHY PEOPLE

NIL

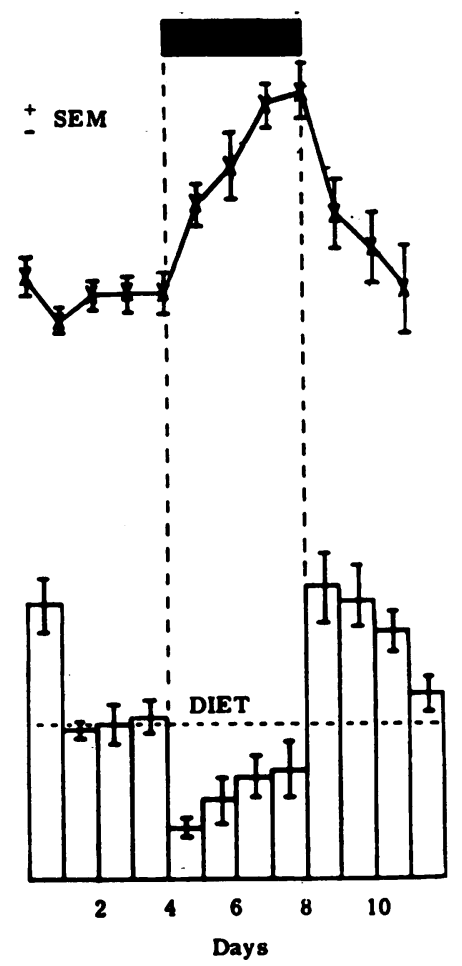

。

$\frac{2}{8}$

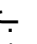

Fig. 8.-Comparison of the long-term metabolic effects of small quantities of angiotensin II in 5 normal people and a patient with wellcontrolled Addison's disease.
Marieb and Mulrow (1964) who cannot stimulate aldosterone or corticosterone secretion from the rat adrenal gland with pressor quantities of angiotensin II. Yet, in the rat, which secretes increased amounts of aldosterone after hæmorrhage (Singer and Stack-Dunne, 1955), there is a positive correlation between the width of the zona glomerulosa and (a) the administration of renin (Deane and Masson, 1951), (b) granularity of the juxtaglomerular cells (Tobian, 1960), and (c) the extractable renin content of the kidneys (Gross, Schaechtelin, Brunner and Peters, 1964). There is also, of course, a negative correlation between the width of the zona glomerulosa and the salt intake (Deane, Shaw and Greep, 1948).

If increased quantities of angiotensin circulate in the blood of patients with secondary hyperaldosteronism, one might expect hypertension to occur. But the blood pressure is usually normal in odematous states whether clinical or experimental. In man it is possible that subpressor quantities of angiotensin stimulate aldosterone production ( $v$. infra) but, in any case, cedematous states are associated with a remarkable resistance to the pressor effects 
of angiotensin and noradrenaline (Johnston and Jose, 1963; Laragh, Cannon, Bentzel, Sicinsky and Meltzer, 1963). Whether this is inherent or merely a result of diuretic therapy is controversial. Hypertensive patients treated with chlorothiazide are relatively resistant to the pressor effects of noradrenaline (Freis, Wanko, Schnaper and Frohlich, 1960), and this appears to be a direct effect of the drug on peripheral resistance vessels (Jackson and Duff, 1963).

Whatever the final outcome, we now know that aldosterone secretion will increase whenever the circulating angiotensin concentration increases; whether the former is actually controlled by the latter under normal circumstances must await further study. However, the idea that the renin-angiotensin system controls aldosterone secretion is particularly attractive because it provides, at least potentially, both affector and effector mechanisms.

\section{More direct effects of angiotensin on sodium excretion}

Even in amounts which have little or no effect on the blood pressure, angiotensin produces an immediate sharp fall in the rate of sodium excretion when infused into normal people (Bock, Dengler, Krecke and Reichel 1958; Gill, Barbour, Slater and Bartter, 1964) which does not depend on the presence of the adrenal glands (Statius Van Eps, SmorenBerg-Schoorl, Zürcher-Mulder, de Vries and Borst, 1962). This is illustrated in Fig. 7. However, over a longer period of time the indirect effect of angiotensin on aldosterone may outweigh the "direct" effects of angiotensin on the kidney. Fig. 6 shows the adrenal and metabolic effects of sub-pressor amounts of angiotensin II infused into normal people. Despite an average weight gain of just over $1 \mathrm{~kg}$. the rate of aldosterone excretion increased when it would otherwise have been expected to decrease. In the one patient with Addison's disease treated with cortisone who was in sodium balance, a 4-day angiotensin infusion had no metabolic effect, although pressor quantities were used (Fig. 8). This serves to emphasise that in small sub-pressor quantities such as are likely to be found physiologically, the effect of angiotensin on sodium excretion is likely to be largely mediated by its effect on aldosterone production.
In hypertensive patients, angiotensin infusiôns often produce an immediate increase rat than a decrease in the rate of sodium excretion (Brown and Peart, 1962). This reversal of the normal response also occurs in patients recestiving salt and large quantities of mineralocofticoid and we have observed it over a longer period in a normotensive Addisonian pationt overtreated with desoxycorticosterone. In shortterm experiments it is impossible to disprave the hypothesis that, under these conditiofis, angiotensin constricts the efferent arteriole. 90 a relatively greater extent than the afferent arteriole. For example, Brown and Peart report that the GFR increases rather than decreases in patients with hypertension. In cirrhosis 3 of the liver, however, Laragh and others (1963) had shown that such a massive outpouring of salt can occur in response to large quarifities of angiotensin, despite minimal changes of GFR, that a tubular effect seems probabłe; and it appears from the stop-flow experimeits of Vander (1963) that angiotensin in normal dogs inhibits distal tubular sodium reabso tion directly. This may also occur in the Eat (Peters, 1963; Gross and others, 1964). $\stackrel{\rho}{\rightarrow}$

These are some facts which will need to be considered in formulating a hypothesis fo the mechanism of action of angiotensin but inçiew of the already numerous biological effects of polypeptide, it is perhaps invidious to atten one until we know more about which effeets are likely to be relevant physiologically.

\section{Conclusion}

This is a necessarily incomplete account $\underset{-0}{ }$ the present state of our knowledge about hormonal mechanisms controlling body sodium. An attempt has been made to stress principtes and to keep an exceedingly complex fietd uncluttered with unresolved detail except when the problems themselves are likely to be stimullating rather than confusing. One important field, for example, which has not been discussed (largely because methodological problems still abound) is the study of the precise factors which control renin release from the kidneys. Nevertheless, the discovery of the likely importance of the renin-angiotensin system in the control of body sodium is perhaps one of the most exciting new developments in the realem of fluid balance since Verney's discovery $q f$ the physiological role of anti-diuretic hormoge.

\section{REFERENCES} August, J. T., Nelson, D. H., and ThoRN, G. W. (1958): Response of Normal Subjects to Large Amoug
of Aldosterone, J. clin. Invest., 37, 1549. 
Barger, A. C., Berlin, R. D., and Tulenko, J. F. (1958): Infusion of Aldosterone, $9 \alpha$-Fluorohydrocortisone and Antidiuretic Hormone into the Renal Artery of Normal and Adrenalectomised, Unanæsthetised Dogs: Effect on Electrolyte and Water Excretion, Endocrinology, 62, 804.

BartTer, F. C. In discussion of Blair-West et al. (1963): Recent Progr. Hormone Res., $19,370$.

BartTer, F. C., GANN, D. S., and Thomas, J. P. (1960): On the Mechanism of Sodium Retention in Cardiac and Hepatic Disease. In 'The Human Adrenal Cortex'. Proc. Conf. Univ. Glasgow, 11th to 14th July, 1960. London: E. \& S. Livingstone.

BartTer, F. C., Lidnle, G. W., Duncan, L. E., Jr., Barber, J. K., and Delea, C. (1956): The Regulation of Aldosterone Secretion in Man: The Role of Fluid Volume, J. clin. Invest., 35, 1306.

BartTer, F.C., Mills, I. H., Biglieri, E. G., and Delea, C. (1959): Studies on the Control and Physiologic Action of Aldosterone, Recent Progr. Hormone Res., 15, 311.

BartTer, F. C., Mills, I. H., and GANN, D. S. (1960): Increase in Aldosterone Secretion by Carotid Artery Constriction in the Dog and its Prevention by Thyrocarotid Arterial Junction Denervation, J. clin. Invest., 39, 1330.

Bartter, F. C., Pronove, P., Gill, J. R., Jr., MacCardle, R. C. (1962): Hyperplasia of the Juxtaglomerular Complex with Hyperaldosteronism and Hypokalemic Alkalosis, Amer. J. Med., 33, 811.

Bell, N. H., SCHEDL, H. P., and BARTTER, F. C. (1964): An Explanation for Abnormal Water Retention and Hyponatremia in Congestive Heart Failure, ibid, 36, 351.

Berliner, R. W., KenNeDY, T. J., Jr., and HiltoN, J. G. (1950): Renal Mechanisms for Excretion of Potassium, Amer. J. Physiol., 162, 348.

Bernard, C. See 'Claude Bernard and his Physiological Works' (1878) ART XVII for full references to his reflections on physiological subjects, Amer. J. med. Sci., 76, 161.

Biglieri, E. G., and GANong, W. F. (1961): Effect of Hypophysectomy on Adrenocortical Response to Bilateral Carotid Constriction, Proc., Soc., exp. Biol., (N.Y.), 106, 806.

Bing, J., and KazimierczaK, J. (1962): Renin Content of Different Parts of the Juxtaglomerular Apparatus, Acta path. microbiol. Scand., 54, 80.

Biron, P., Kiow, E., NoWACYNSKI, W., Brouillet, J., and Genest, J. (1961): The Effects of Intravenous Infusions of Valine-5-angiotensin II and other Pressor Agents on Urinary Electrolytes and Corticosteroids including Aldosterone, J. clin. Invest., 40, 338.

Black, D. A. K., Platt, R., and Stanbury, S. W. (1950): Regulation of Sodium Excretion in Normal and Salt-deplated Subjects, Clin. Sci., 9, 205.

Blair-West, J. R., Coghlan, J. P., Denton, D. A., Goding, J. R., Munro, J. A., Peterson, R. E., and WINTOUR, M. (1962): Humoral Stimulation of Adrenal Cortical Secretion, J. clin. Invest., 41, 1606.

Blair-West, J. R., Coghlan, J. P., Denton, D. A., Goding, J. R., Wintour, M., and Wright, R. D. (1963): The Control of Aldosterone Secretion, Recent. Progr. Hormone Res., 19, 311.

Bock, K. D., Dengler, H., KRECKE, H. J., and ReICHEL, G. (1958): Untersuchungen über die Wirkung von Synthetischem Hypertensin II auf Elektrolythaushalt, Nierenfucktich und Kreislauf beim Menschen, Klin. Wschr., 36, 808.

Boucher, R., Veyrat, R., De Champlain, J., and Genest, J. (1964): New Procedures for Measurement of Human Plasma Angiotensin and Renin Activity Levels, Canad. med. Ass. J., 90, 194.

Brown, J. J., Davies, D. L., LeVer, A. F., and RoberTson, J. I. S. (1964): Variations in Plasma Renin Concentration in Several Physiological States, ibid, 90, 201.

Brown, J. J., and PEART, W. S. (1962): The Effect of Angiotensin on Urine Flow and Electrolyte Excretion in Hypertensive Patients, Clin. Sci., 22, 1.

CARPENTER, C. C. J., Davis, J. O., and AYers, C. R. (1961): Concerning the Role of Arterial Baroreceptors in the Control of Aldosterone Secretion, J. clin. Invest., 40, 1160.

Carpenter, C. C. J., Davis, J. O., and Ayers, C. R. (1961): Relation of Renin, Angiotensin II, and Experimental Renal Hypertension to Aldosterone Secretion, J. clin. Invest., 40, 2026.

Chalmers, T. M., Lewis, A. A. G., and Pawan, G. L. S. (1952): The Effect of Acute Reduction of the Glomerular Filtration Rate on Sodium Excretion in Man, J. Physiol., 117, 218.

Coghlan, J. P., Denton, D. A., Goding, J. R., Wright, R. D. (1960): The Control of Aldosterone Secretion, Postgrad. med. J., 36, 76.

Cook, W. F., and Pickering, G. W. (1959): The Location of Renin within the Kidney, J. Physiol., 149, 526.

Crabbe, J., Ross, E. J., and Thorn, G. W. (1958): The Significance of the Secretion of Aldosterone during Dietary Sodium Deprivation in Normal Subjects, J. clin. Endocr., 18, 1159.

DAviS, J. O. (1960): Mechanisms of Salt and Water Retention in Congestive Heart Failure, Amer. J. Med., $24,486$.

Davis, J. O., Bahn, R. C., Yankopoulos, N. A., Kliman, B., and Peterson, R. E. (1959): Acute Effects of Hypophysectomy and Diencephalic Lesions on Aldosterone Secretion, Amer. J. Physiol., 197, 380.

Davis, J. O., Carpenter, C. C. J., AYers, C. R., and BAHN, R. C. (1960): Relation of Anterior pituitary Function to Aldosterone and Corticosterone Secretion in Conscious Dogs, Amer. J. Physiol., 199, 212.

Davis, J. O., Carpenter, C. C. J., AYers, C. R., Holman, J. E., and Bahn, R. C. (1961): Evidence for Secretion of an Aldosterone-stimulating Hormone by the Kidney, J. clin. Invest., 40, 684.

Davis, J. O., Goopkind, M. J., PeChET, M.M., and Ball, W. C., Jr. (1956): Increased Excretion of Aldosterone in Urine from Dogs with Right-sided Congestive Heart Failure and from Dogs with Thoracic Inferior Vena Cava Constriction, Amer. J. Physiol., 187, 45.

DAvis, J. O., HIGGINS, J. T., and URQuHART, J. (1964): Evidence for an Increased Plasma Level of Renin in Experimental Secondary Hyperaldosteronism, Fed. Proc., 23, 301.

DAvis, J. O., Howell, D. S., and SouthwORTH, J. L. (1953): Mechanisms of Fluid and Electrolyte Retention in Experimental Preparations in Dogs: III Effect of Adrenalectomy and Subsequent Desoxycorticosterone Acetate Administration on Ascites Formation, Circ. Res., 1, 260. 

Deane, H. W., and Masson, G. M. C: (1951): Adrenal Cortical Changes in Rats with Various Typa
of Experimental Hypertension, J. clin. Endocr., 11, 193.

Deane, H. W., Shaw, J. H., and Greep, R. O. (1948): The Effect of Altered Sodium or Potassium Intake on the Width and Cytochemistry of the Zona Glomerulosa of the Rat's Adrenal Cortex Endocris ology, 43, 133.

Denton, D. A., Goring, J. R., and Wright, R. D. (1959): Control of Adrenal Secretion of Electrolytê active Steroids, Brit. med. J., ii, 447, 522.

de Wardener, H. E. Mills, I. H., Clapham, W. F., and Hayter, C. J. (1961): Studies on the Efferent Mechanism of the Sodium Diuresis which Follows the Administration of Intravenous Saline in the Dog Clin. Sci., 21, 249.

Duncan, L. E., LidDle, G. W., and BartTer, F. C. (1956): The Effect of Changes in Body Sodium of Extracellular Fluid Volume and Aldosterone and Sodium Excretion by Normal and Edematous MeR J. clin. Invest., 35, 1299.

EPSTEIN, F. H. (1956): Renal Excretion of Sodium and the Concept of a Volume Receptor, Yale J. biö Med., 29, 282.

EPSTEIN, F. H., Post, R. S., McDowell, M. (1953): The Effect of an Arteriovenous Fistula on Renal Hemodynamics and Electrolyte Excretion, J. clin. Invest., 32, 233.

Farrel.l, G. (1958): Regulation of Aldosterone Secretion, Physiol. Rev., $38,709$.

Farrell, G. (1959): Steroidogenic Properties of Extracts of Beef Diencephalon, Endocrinology, 65, 29. $\frac{2}{8}$

FARRell, G. (1959): Glomerulotropic Activity of an Acetone Extract of Pineal Tissue, ibid, 65, 239.

FARrell, G. (1960): Adrenoglomerulotrophin, Circulation, 21, 1009.

FAsciolo, J. C., DE Vito, E., Romero, J. C., and CucCHI, J. N. (1964): The Renin Content of the Bloof of Humans and Dogs under Several Conditions, Canad. med. Ass. J., 90, 206. FeldberG, W., and LewIS, G. P. (1964): The Action of Peptides on the Adrenal Medulla. Release @
Adrenaline by Bradykinin and Angiotensin, J. Physiol., 171, 98.

Freis, E. D., WaNko, A., Schnaper, H. W., and Frohlich, E. D. (1960): Mechanism of the Alteret Blood Pressure Responsiveness produced by Chlorothiazide, J. clin. Invest., 39, 1277.

Ganong, W. F., and Mulrow, P. J. (1958): Rate of Change in Sodium and Potassium Excretion afteी Injection of Aldosterone into the Aorta and Renal Artery of the Dog, Amer. J. Physiol., 195, 337.

Ganong, W. F., and Mulrow, P. J. (1962): Role of the Kidney in Adrenocortical Response to Hæmorrhage in Hypophysectomised Dogs, Endocrinology, 70, 182.

Garrod, O., Davies, S. A., and CaHill, G. (1955): The Action of Cortisone and Desoxycorticosterone Acetate on Glomerular Filtration Rate and Sodium and Water Exchange in the Adrenalectomised Do\& J. clin. Invest., 34, 761 .

Gill, J. R., Jr., Barbour, B. H., Slater, J. D. H., and BartTer, F. C. (1964): Effect of Angiotensiro on Urinary Dilution in Normal Man, Amer. J. Physiol., 206, 750.

Giroud, C. J. P., Kalant, N., Despointes, R. H., and Dasgupta. D. (1961): Mechanisms of Edêjig Formation in Experimental Nephrosis, Recent Progr. Hormone Res., 17, 353.

GoldblatT, H., Lynch, J., Hanzal, R. F., and Summerville, W. W. (1934): Studies on Experimental Hypep tension: The Production of Persistent Elevation of Systolic Blood Pressure by Means of Renal Ischæmiæa J. exper. Med., 59, 347.

Goormaghtigh, N. (1945): Facts in Favour of an Endocrine Function of the Renal Arterioles, J. Pat Bact., 57, 392. Gould, A. B., Skeggs, L. T., KaHN, J. R. (1964): The Presence of Renin Activity in Blood Vess $\overrightarrow{3}$
Walls, J. exper. Med., 119, 389.

Gross, F., and LichtLen, P. (1958): Experimental Renal Hypertension and Renin Content of Kidneys in Intact and Adrenalectomised Rats given Cortexone, Amer. J. Physiol., 195, 543.

Gross, F., Schaechtelin, G., Brunner, H., and Peters, G. (1964): The Role of the Renin-angiotensî̀ System in Blood Pressure Regulation and Kidney Function, Canad. med. Ass. J., 90, 258.

Grundy, H. M., Simpson, S. A., and TAIT, J. F. (1952): Isolation of a Highly Active Mineralocortico from Beef Adrenal Extract, Nature (Lond.), 169, 759.

Hartroft, P. M., Sutherland, L. E., and HARTrofT, W. S. (1964): Juxtaglomerular Cells as the Source of Renin: Further Studies with the Fluorescent Antibody Technique and the Effect of Passive Transfe? of Antirenin, Canad. med. Ass. J., 90, 163.

IngLe, D. J. (1952): The Role of the Adrenal Cortexin Homeostasis, J. Endocr., 8, xxiii.

JACKSON, E., and DufF, R. S. (1963): Effect of Chlorothiazide on Noradrenaline Vasoconstriction in Mam Clin. Sci., 24, 23.

Johnston, C. I., and Jose, A. D. (1963): Reduced Vascular Response to Angiotensin II in Secondar
Hyperaldosteronism, J. clin. Invest., 42, 1411.

Kagawa, C. M., Cella, J. A., and Van Arman, G. C. (1957): Action of New Steroids in Blocking Effects of Aldosterone and Desoxycorticosterone on Salt, Science, 126, 1015.

Lampin, E., Kleeman, C. R., Rubini, M., and Epstein, F. H. (1956): Studies on Alcohol Diuresis. If The Response to Ethyl Alcohol in Certain Disease States Characterised by Impaired Water Tolerances J. clin. Invest., 35, 386.

Laragh, J. H., CanNon, P. J., Bentzel, C. J., Sicinsky, A. M., and Meltzer, J. I. (1963): Angiotensín II, Norepinephrine and Renal Transport of Electrolytes and Water in Normal Man and in Cirrhoses with Ascites, J. clin. Invest., 42, 1179.

Laumas, K. R., TAIT, J. F., and TAIT, S. A. S. (1961): The Validity of the Calculation of Secretion Rates from the Specific Activity of a Urinary Metabolite, Acta Endocr. (Kbh.), 36, 265.

LidDle, G. W. (1958): Aldosterone Antagonists, Arch. intern. Med., 102, 998.

LIDDle, G. W., Duncan, L. E., and BARTTER, F. C. (1956): Dual Mechanism Regulating Adrenocorticä Funotion in Man, Amer. J. Med., 21, 380. 
Lipsett, M. B., and Pearson, O. H. (1958): Sodium Depletion in Adrenalectomised Humans, J. clin. Invest., 37, 1394.

LeUTSCHER, J. A., and Johnson, B. B. (1954): Observations on the Sodium-Retaining Corticoid (Aldosterone) in the Urine of Children and Adults in Relation to Sodium Balance and Edema, ibid., 33, 1441.

Marieb, N. J., and Mulrow, P. J. (1964): The Response of Aldosterone Secretion to Angiotensin in the Rat, Fed. Proc., 23, 300.

McCance, R. A., and Widdowson, E. M. (1937): The Secretion of Urine in Man during Experimental Salt Deficiency, J. Physiol., 91, 222.

MacLean, J. P., Lipsett, M. B., Li, M. C., West, C. D., and Pearson, O. H. (1957): Regulation of Salt Metabolism after Hypophysectomy in Man, J. clin. Endocr., 17, 346.

Merrill, A. J. (1946): Fdema and Decreased Renal Blood Flow in Patients with Chronic Congestive Heart Failure: Evidence of 'forward failure' as the Primary Cause of Oedema, J. clin. Invest., $25,389$.

Mills, J. N. (1963): The Part Played by the Adrenals in Human Circadian Renal Rhythms, Proc. roy. Soc. Med., 56, 259.

Mueller, C. B., Surtshin, A., Carlin, M. R., and White, H. L. (1951): Glomerular and Tubular Influences on Sodium and Water Excretion, Amer. J. Physiol., 165, 411.

Mulrow, P. J., Ganong, W. F., Cera, G., and Kuljian, A. (1962): The Nature of the Aldosteronestimulating Factor in Dog Kidneys, J. clin. Invest., 41, 505.

O'ConNOR, W. J. (1962): 'Renal Function'. London: Edward Arnold.

Page, I. H., and Bumpus, F. M. (1961): Angiotensin,Physiol. Rev., 41, 331.

Peters, G. (1963): Renal Tubular Effect of Val-angiotensin II Ámide in Rats, Proc. Soc. exp. Biol., (N.Y.) 112, 771.

Peterson, R. E. (1959): The Miscible Pool and Turnover Rate of Adrenocortical Steroids in Man, Recent Progr. Hormone Res., 15, 231.

Pitcock, J. A., Hartroft, P. M., and Newmark, L. N. (1959): Increased Renal Pressor Activity (Renin) in Sodium Deficient Rats and Correlation with Juxtaglomerular Cell Granulation, Proc. Soc. exp. Biol., $(N . Y), 100,868$.

Ralli, E. P., Leslie, S. H., Stueck, G. H., Jr., and LAKeN, B. (1951): Studies of the Serum and Urine Constituents in Patients with Cirrhosis of the Liver during Water Tolerance Tests, Amer. J. Med., 11, 157.

Rosenbaum, J. D., Papper, S., and Ashley, M. M. (1955): Variations in Renal Excretion of Sodium Independent of Change in Adrenocortical Hormone Dosage in Patients with Addison's Disease, J. clin. Endocr., 15, 1459.

Ross, E. J., and WINTERnitz, W. W. (1961): The Effect of an Aldosterone Antagonist on the Renal Response to Sodium Restriction, Clin. Sci., 20, 143.

RUYTER, J. H. C. (1925): Uber einen Merkwürdigen Abschnitt der Vasa afferentia in der Mäuseniere, $Z$. Zellforsch, 2, 242.

SchedL, H. P., and Barter, F. C. (1960): An Explanation for and Experimental Correction of the Abnormal Water Diuresis in Cirrhosis, J. clin. Invest., 39, 248.

Scornik, O. A., and Paladini, A. C. (1964): Significance of Blood Angiotensin Levels in Different Experimental Conditions, Canad. med. Ass. J., 90, 269.

Selkurt, E. E. (1951): Effect of Pulse Pressure and Mean Arterial Pressure Modification on Renal Hæmodynamics and Electrolyte and Water Excretion, Circulation, 4, 541.

Singer, B. and STACK-DunNe, M. P. (1955): Secretion of Aldosterone and Corticosterone by the Rat Adrenal, J. Endocr., 12, 130.

Skelton, R. R., Chandra, S., and Bernardis, L. L. (1964): Separation of Renal Pressor Activity by Ultracentrifugation, Fed. Proc., 23, 544.

Slater, J. D. H. (1960): Aldosterone Antagonism by 17-Spirolactosteroids, Postgrad. med. J., $36,399$.

Slater, J. D. H. (1963): In discussion of BlaIr-West et al., Recent Progr. Hormone Res., 19, 381.

Slater, J. D. H., Barbour, B. H., Henderson, H. H., Casper, A. G. T., and BarTter, F. C. (1963): Influence of the Pituitary and the Renin-angiotensin System on the Secretion of Aldosterone, Cortisol and Corticosterone, J. clin. Invest., 42, 1504.

Slater, J. D. H., Barbour, B. H., Henderson, H. H., Casper, A. G. T., and Bartter, F. C. (1964): Physiological Influence of the Kidney on the Secretion of Aldosterone, Corticosterone and Cortisol by the Adrenal Cortex. In press.

Slater, J. D. H., Mestitz, P., Walker, G., and Nabarro, J. D. N. (1961): The Acute Effects of Infused Adrenal Steroids on Renal Function in Adrenolectomised Dogs, Acta Endocr. $(K b h), 37,263$.

Smith, H. W. (1957): Salt and Water Volume Receptors, Amer. J. Med., $23,623$.

Statius van EPS, L. W., SMOREN-Berg-Schoorl, M. E. Zurcher-Mulder, A., De VRIES, L. A., and Borst, J. G. G. (1962): Identical Changes in Renal Excretion Pattern Induced by Angiotensin and Orthostasis in Normal and Adrenalectomised Subjects, Acta med. scand., 171, 153.

Strauss, M. (1957): 'Body Water in Man'. London: Churchill.

Surtshin, A., Rolf, D., and White, H. L. (1951): Constancy of Sodium Excretion in the Presence of Chronically Altered Filtration Rate, Amer. J. Physiol., 165, 429.

SwanN, H. G. (1940): The Pituitary-adrenocortical Relationship, Physiol. Rev., $20,495$.

ThorN, G. W., Ross, E. J., CRABbe, J., and VaN'T HofF, W. (1957): Studies on Aldosterone Secretion in Man, Brit. med. J., ii, 955 .

Tigerstedt, R., and Bergman, P. C. (1898): Niere und Kreislauf, Skand. Arch. Physiol., 8, 223.

Tobian, L. (1960): Physiology of the Juxtaglomerular Cells, Ann. intern. Med., 52, 395.

Urquhart, J., Davis, J. O., and Higgins, J. T. (1963): The Effects of Alterations of Plasma Sodium and Potassium Concentration on Aldosterone Secretion, J. clin. Invest., 42, 597. 
Van Brunt, E. E., Biglieri, E. G., and Ganong, W. F. (1964): Aldosterone Secretion in Dogs Treated wi wh Hog Renin, Fed. Proc., 23, 301.

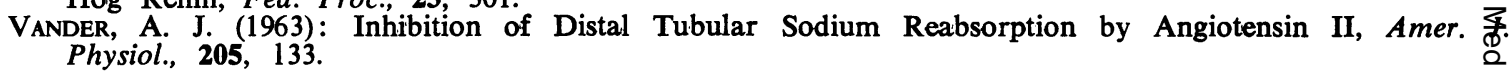

Vander, A. J., Malvin, R. L., Wilde, W. S., Lapides, J., Sullivan, L. P., and McMurray, V. M. (19589: Effects of Adrenalectomy and Aldosterone on Proximal and Distal Tubular Sodium Reabsorption, Pros. Soc. exp. Biol., (N.Y.), 99, 323.

Wesson, L. G. (1957): Glomerular and Tubular Factors in the Renal Excretion of Sodium Chloride, Medicine, 36, 281 .

Yankopoulos, N. A., Davis, J. O., Kliman, B., and Peterson, R. E. (1959): Evidence that a Humori: Agent Stimulates the Adrenal Cortex to secrete Aldosterone in Experimental Secondary Hypet: aldosteronism, J. clin. Invest., 38, 1278. 